\title{
Contrasting Trends in Abundance of Indian Vultures (Gyps indicus) Between Two Study Sites in Neighboring Indian States
}

\author{
Christopher J. W. McClure ${ }^{1,2 *}$, Brian W. Rolek ${ }^{1}$ and Munir Z. Virani ${ }^{1,3}$ \\ ${ }^{1}$ The Peregrine Fund, Boise, ID, United States, ${ }^{2}$ School of Animal, Plant and Environmental Sciences, University of the \\ Witwatersrand, Johannesburg, Johannesburg, South Africa, ${ }^{3}$ Department of Zoology, National Museums of Kenya, Nairobi, \\ Kenya
}

\section{OPEN ACCESS}

Edited by:

Virginia Morandini,

Oregon State University,

United States

Reviewed by:

Iñigo Zuberogoitia, Independent Researcher,

Bilbao, Spain

Jonah Henri Ratsimbazafy,

Madagascar Primate Study

and Research Group, Madagascar

*Correspondence:

Christopher J. W. McClure cmcclure@peregrinefund.org

Specialty section:

This article was submitted to

Conservation and Restoration

Ecology,

a section of the journal

Frontiers in Ecology and Evolution

Received: 14 November 2020

Accepted: 06 May 2021

Published: 02 June 2021

Citation:

McClure CJW, Rolek BW and Virani MZ (2021) Contrasting Trends in Abundance of Indian Vultures (Gyps indicus) Between Two Study Sites

in Neighboring Indian States.

Front. Ecol. Evol. 9:629482.

doi: 10.3389/fevo.2021.629482
Indian Vultures (Gyps indicus) are critically endangered, yet are poorly monitored. We analyze counts of breeding pairs of Indian Vultures in Central India, specifically the eastern portions of the Indian states of Rajasthan and Madhya Pradesh over a period of 10 years and reveal the populations were on differing trajectories from 2007 to 2016. The difference between population levels of the study areas nearly doubled during our study, with the population in Rajasthan declining relative to Madhya Pradesh. Future research should examine potential drivers of population declines and establish a longterm monitoring program that informs current conservation strategies for Indian and other vultures across their range.

Keywords: diclofenac, Gyps indicus, Indian Vulture, Long-billed Vulture, non-steroidal anti-inflammatory drug

\section{INTRODUCTION}

Evidence of large-scale declines in raptor populations highlights the need for extensive and rigorous monitoring programs to document species occurrence and to detect population changes (McClure et al., 2018; Buechley et al., 2019). A vulture crisis occurred first in south Asia and then subsequently across Africa (Pain et al., 2008; Buechley and Şekercioğlu, 2016; Ogada et al., 2016). Old World vultures are more threatened and their populations declining faster than other groups of birds (Buechley and Şekercioğlu, 2016; McClure et al., 2018), mostly because of various forms of poisoning (e.g., Oaks et al., 2004; Ogada et al., 2012; McClure et al., 2018).

During the late 1990s and early 2000s, populations of three species of Gyps vulture across southern Asia fell by > 95\% (Prakash, 1999; Gilbert et al., 2002; Prakash et al., 2003, 2012; Oaks et al., 2004). These populations were decimated by veterinary use of non-steroidal anti-inflammatory drugs (NSAIDs), particularly diclofenac (Oaks et al., 2004; Pain et al., 2008; Ogada et al., 2012; Margalida and Ogada, 2018). These drugs are nephrotoxic to birds and cause renal failure in vultures (Oaks et al., 2004).

In 2006, the governments of India, Pakistan, and Nepal responded to these population declines by banning the importation, production, and sale of veterinary diclofenac (Pain et al., 2008; Margalida and Ogada, 2018). Following these regulations, as well as the promotion of nontoxic meloxicam as an alternative to diclofenac (Swan et al., 2006; Swarup et al., 2007), some populations of Gyps vultures in southern Asia seem to have stabilized (Chaudhry et al., 2012; Prakash et al., 2012). Less than one percent of livestock carcasses need to be contaminated with 
diclofenac to cause catastrophic population declines in Gyps vultures (Green et al., 2004). Therefore, despite some conservation successes, populations of Gyps vultures across much of southern Asia remain threatened by illegal use of diclofenac (Cuthbert et al., 2011a,b) and use of other legal, yet toxic, NSAIDS (Cuthbert et al., 2007, 2016; Naidoo et al., 2010). Indeed, the White-rumped (Gyps bengalensis), Slender-billed (Gyps tenuirostris), and Indian (Gyps indicus) Vultures remain Critically Endangered (BirdLife International, 2021). In India's north-eastern state of Assam, the use of poisoned-laced carcasses in retaliation by farmers to livestock depredation by feral dogs has resulted in a spate of vulture mortalities further compounding the problem (Pandey et al., in prep). Unpublished reports exist of vulture mortalities as a result of collisions with energy infrastructure in the state of Gujarat, India (Shastri, pers comm).

The International Union for the Conservation of Nature (IUCN) recommends population monitoring for Indian Vultures (BirdLife International, 2021). Here we analyze counts of breeding pairs of Indian Vultures within study areas in the eastern portions of the Indian states of Madhya Pradesh and Rajasthan over a period of 10 years - from 2007 to 2016. Comparisons of trends in abundance between two areas can reveal population dynamics and potential threats (Green, 1995, 1999, 2002). An increasing difference between populations within these two study areas in neighboring states might reveal potentially important management actions, or lack thereof, implemented by one state, but not the other.

\section{METHODS}

We began preliminary surveys in December 2002 in the eastern portions of the states of Rajasthan and Madhya Pradesh with the aim of identifying all Indian Vulture colonies in those areas that could be regularly monitored on an annual basis. From 2002 to 2006, additional sites were added as we became more familiar with the study areas and obtained local knowledge of vulture colonies. By 2007, we were confident that we had identified all potential nesting cliffs in our study areas. We therefore analyzed data from 2007 to 2016 .

\section{Study Areas}

In Rajasthan (Figure 1), we conducted surveys at the following places: Chambal River Gorge near Kota, various cliff faces in Ranthambore National Park, the villages of Bodal, Hindwar, and Nimli in the outskirts of Ranthambore. Ranthambore $\left(25^{\circ} 97.2^{\prime}\right.$ $\mathrm{N}, 76^{\circ} 44.9^{\prime} \mathrm{E}$ ) covers an area of $1,334 \mathrm{~km}^{2}$ (core area $=392 \mathrm{~km}^{2}$ ) and lies in south-east Rajasthan where the Vindhyas and Aravalli Hills converge. The terrain consisted of hills with cliffs faces, valleys, and riverine forests. Dhok (Anogeissus pendula) was the dominant tree species while Khair (Acacia catechu) was prevalent in the valleys. The Vindhya hills that meandered through the village harbored scattered colonies of Indian Vultures. The barrage at Kota and $20 \mathrm{~km}$ downstream the Chambal River comprised cliffs on either side that also harbored scattered colonies of Indian Vultures.
In Madhya Pradesh (Figure 1), we conducted surveys at the major cliff faces in Bandhavgarh National Park, and the villages of Jukehi, Kymore, and Gidhaila Pahad - all part of the Khemur Range. Bandhavgarh $\left(23^{\circ} 68.1^{\prime} \mathrm{N}, 81^{\circ} 04.4^{\prime}\right)$ covered an area of $448 \mathrm{~km}^{2}$ (core area $=105 \mathrm{~km}^{2}$ ) and consisted of Sal forest with bamboo (Bambusa vulgaris), open grasslands, and a number of rocky outcrops and plateaus that provide suitable nesting ledges for Indian Vultures and other cliff-nesting raptors. Both Ranthambhore and Bandhavgarh National Parks are part of India's Project Tiger initiated in 1973 to help safeguard populations of tigers (Panthera tigris; Moulton and Hulsey, 2002). All parks consisted of a central core area, where agricultural activities were excluded. These were surrounded by a buffer area where subsistence agricultural activities and livestock grazing occur, but where the natural vegetation was still relatively intact.

\section{Surveys}

We used the number of occupied nests per season as an index of breeding population. We followed the criteria of Postupalsky (1974) requiring a minimum of two visits per season. We further adapted our methodology to that of Benson and McClure (2020) to estimate and compare trends in abundance between the two states. Nests were considered occupied (sensu Franke et al., 2017) when an egg or nestling was present, or when adults exhibited nesting behaviors such as an observation of a vulture crouching low on the nest as if incubating, copulation, or bringing in nest material. We recorded all vulture nesting sites and determined their locations using a hand-held GPS unit. Each nest site was photographed and nests were given an alpha-numeric code to help facilitate data collection. We conducted two surveys during the breeding season - the first occurred during the first 2 weeks of December when eggs of Indian Vultures had been laid or nests were still being built. The second survey took place during the last 2 weeks of March, sometimes including the first week of April. During this time, large nestlings were conspicuous in the nests. All surveys were conducted using spotting scopes either from an open vehicle or by foot.

Gilbert et al. (2007) and Khatri (2013) have documented the home ranges of Gyps vultures in India and suggested substantially smaller home ranges during the nesting season compared to the late breeding and post-fledgling periods. Based on this and the distance between the central points of two study sites in Rajasthan and Madhya Pradesh (c. $750 \mathrm{~km}$ ), our analysis assumed that from a breeding and foraging perspective, these were two different populations and justified comparisons between each.

\section{Analysis}

We used a Markovian state-space model within a Bayesian framework that estimates an index of yearly abundances of Indian Vultures in each state. State-space models are useful for estimating imperfectly observed abundances because they separate observation error from process variance in count data (Kéry and Schaub, 2012). We modified [Kéry and Schaub's (2012): p. 127] R (R Core Team, 2019) code that models counts $\left(y_{\mathrm{t}}\right)$ during each year $(t)$ with a mean $\left(\mu_{\mathrm{t}}\right)$ that accounts for observation error $\left(\sigma_{\mathrm{OBS}}\right)$ as $y_{\mathrm{t}} \sim \operatorname{normal}\left(\mu_{\mathrm{t}}, \sigma_{\mathrm{OBS}}\right)$. We specified temporal dynamics after the first year as $\log N_{\mathrm{t}+1}=$ 


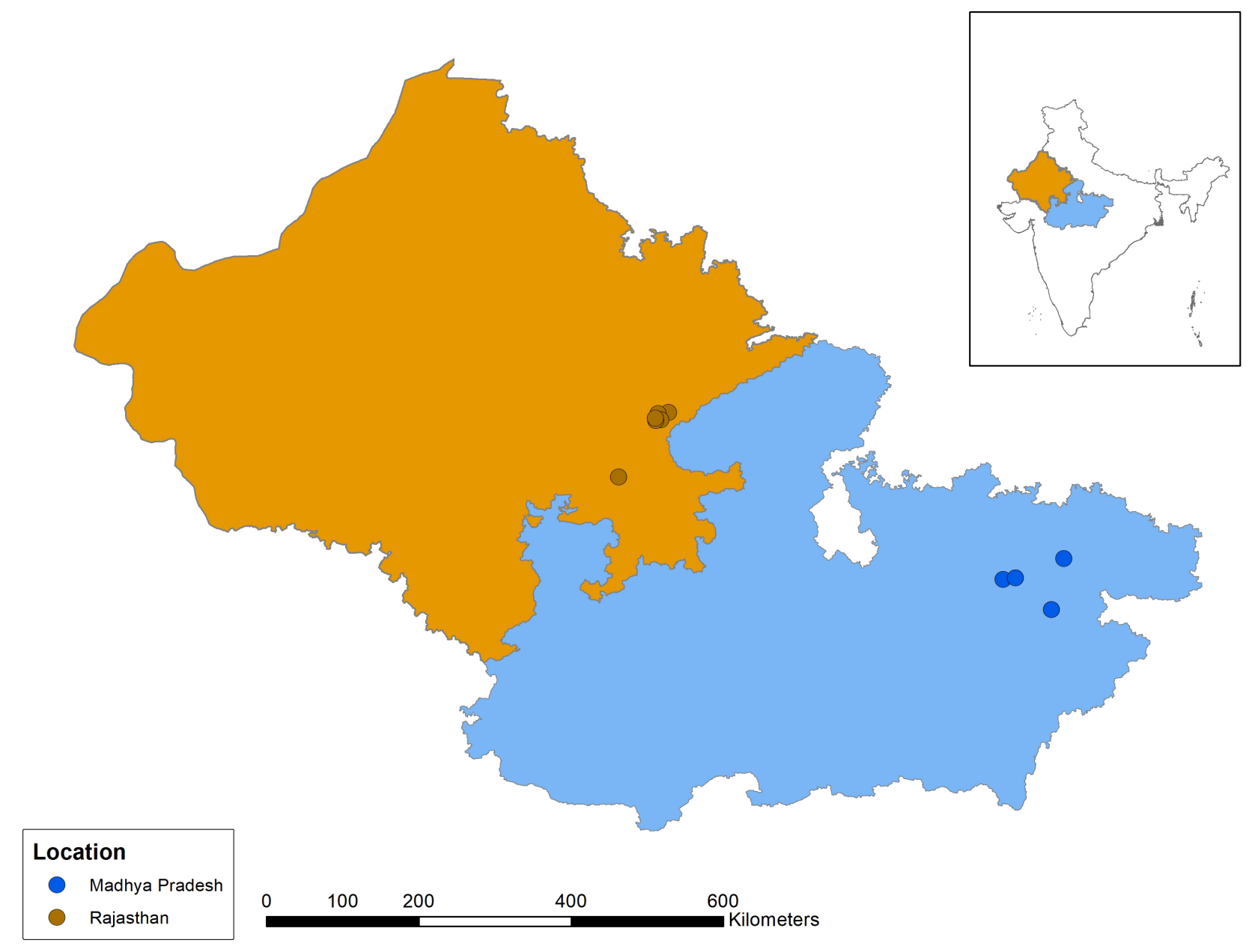

FIGURE 1 | Map of our study sites (points) in the Indian states of Madhya Pradesh (blue, East) and Rajasthan (orange, West).

$\log N_{\mathrm{t}}+r_{\mathrm{t}}$ where $N_{\mathrm{t}}$ was an index of abundance for a given year and $N_{\mathrm{t}+1}$ was an index of abundance during the following year, and $r_{\mathrm{t}}$ was the population growth rate from year $t$ to $t+1$. In this model, the population growth rate for each year was a random variable with a normally distributed mean, $r_{\mathrm{t}} \sim \operatorname{normal}\left(\gamma, \sigma_{\mathrm{R}}\right)$ (Kéry and Schaub, 2012). Model-estimated parameters represented the mean population growth rate $(\gamma)$ and process error $\left(\sigma_{R}\right)$ over the entire study. We used identical models (described above) for each state and derived differences between the states and calculated the difference between

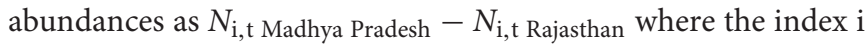
represented each retained posterior iteration, thereby providing a posterior distribution for the difference between abundances. We implemented Bayesian models using JAGS (Plummer, 2003) and the package jagsUI (Kellner, 2016) in R and implemented three MCMC chains each having 40,000 posterior iterations with burnin of 10,000 and the posterior was thinned by retaining one of six iterations. We specified vague or weakly informative priors, $\gamma \sim$ $\operatorname{normal}(0, \tau=0.001) ; \sigma \sim$ uniform $(0,1)$ for all error terms; and priors for initial abundance had means near observed counts for each site on the $\log$ scale, $\log N_{\mathrm{t}} \sim \operatorname{Normal}(-0.8, \tau=0.01)$. We calculated the Gelman-Rubin statistic (Gelman and Rubin, 1992) and considered convergence of chains when parameters had an $\hat{R}<1.1$. We visually assessed trace plots of parameter chains to confirm convergence and used vague priors for all parameters (Kéry and Schaub, 2012). We used the $\operatorname{lm}()$ function in R to conduct regressions of posterior draws (Benson and McClure, 2020) of the differences between state abundances against year to estimate a linear trend.

\section{RESULTS}

We monitored a total of 2,397 potential nesting ledges of which $1,183(49.4 \%)$ were in Rajasthan and 1,214 (50.6\%) in Madhya Pradesh. Of these, $686(58 \%)$ and $723(60 \%)$ were occupied at least once in Rajasthan and Madhya Pradesh, respectively. Per year, the average number of occupied nesting sites was 173.67 $(\mathrm{SD}=23.24)$ in Rajasthan and $224.33(\mathrm{SD}=21.16)$ in Madhya Pradesh (Figure 2 and Supplementary Table 1).

The average population growth rate in Madhya Pradesh was $0.007(\mathrm{SD}=0.011)$, whereas in Rajasthan it was -0.017 

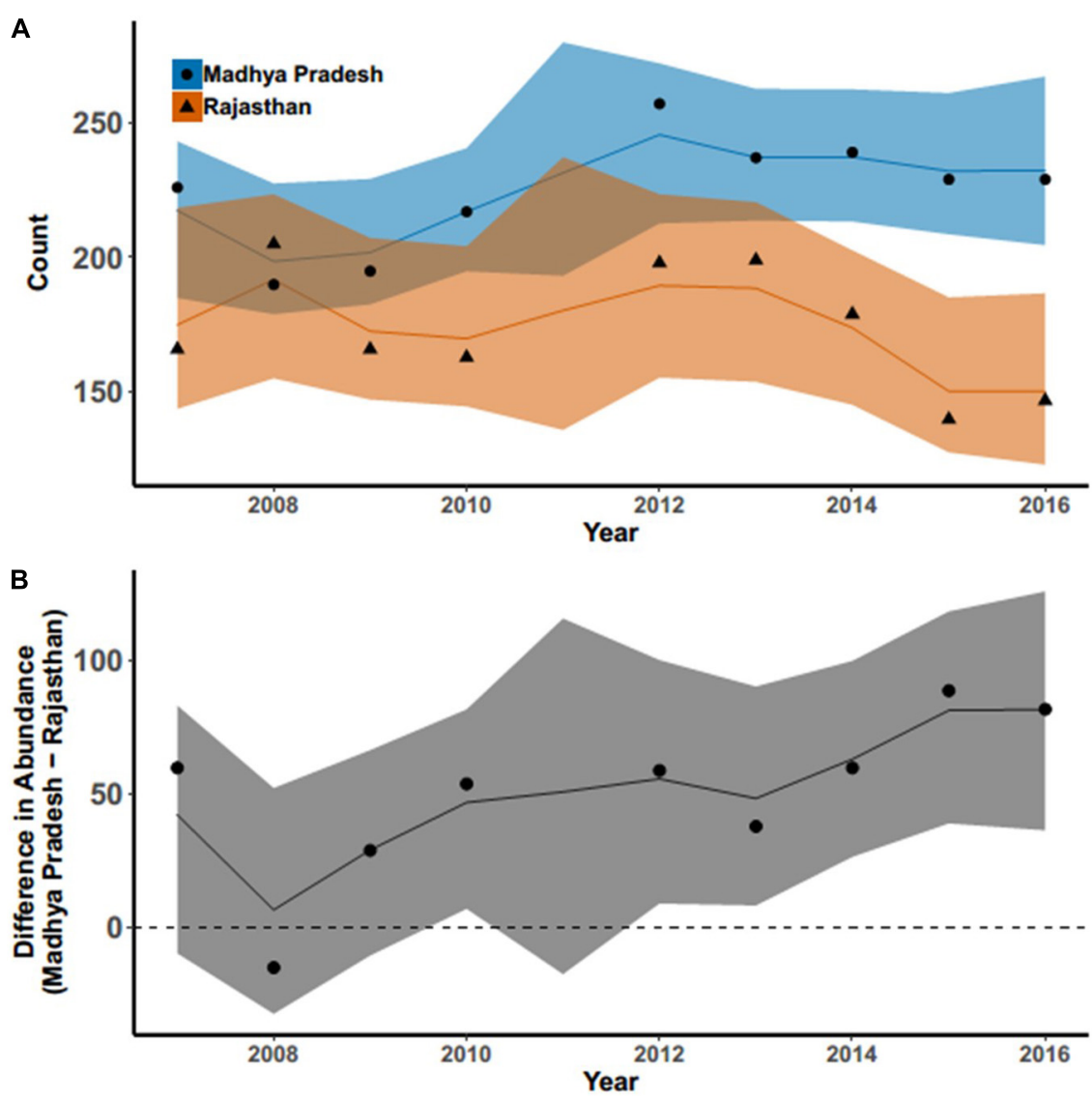

FIGURE 2 | (A) Observed (points) and estimated (lines, shaded areas = 95\% CRIs) counts of occupied Indian Vulture nests within the Indian states of Madhya Pradesh (circles, blue) and Rajasthan (triangles, orange). (B) Observed (points) and estimated (line, shaded area = 95\% CRls) differences between yearly counts of occupied Indian Vulture nests within study sites in the eastern portions of the Indian states of Madhya Pradesh and Rajasthan. The dashed line at zero represents no difference between the two states.

$(\mathrm{SD}=0.016)$. The difference between these growth rates was 0.024 $(\mathrm{SD}=0.029)$ and the probability that the two rates were different was $92.3 \%$. The slope in the differences between states per year was $6.421(\mathrm{SD}=3.055)$ with an $R^{2}$ of $0.465(\mathrm{SD}=0.225)$. There was a $97.6 \%$ probability that the slope was positive, indicating an increase in the differences between abundances between the two states during 2007-2016. Indeed, at the beginning of the study Madhya Pradesh had 42.206 (SD = 23.970) more pairs than Rajasthan, yet by the end of the study the difference had nearly doubled (82.040; SD = 21.149; Figure 2).

\section{DISCUSSION}

The difference in population levels of Indian Vultures within our study sites in the neighboring states of Madhya Pradesh and Rajasthan increased over the course of our study. These populations appeared to have different population trajectories from 2007 to 2016. Our results support those of Prakash et al. (2019) who suggested slowly declining populations of Indian Vultures from 2000 to 2013. A study of the State of India's Birds (SoIB, 2020) indicates a highly concerning and strongly declining trend of Indian Vultures across India which matches our declining population trend in Rajasthan.

Green (2002) presented several steps toward diagnosing causes of population declines. Our study directly addresses the first step: Assess the evidence for a decline in population or range. That the population in our study site in eastern Rajasthan is progressively declining relative to the statistically stable population in eastern Madhya Pradesh is cause for concern. Yet, our study is correlative and occurs over a short time period relative to the generation time of the species (18.3 years; BirdLife International, 2021). Our results are therefore justification for further study rather than for immediate alarm.

The second and third steps prescribed by Green (2002) are to study the natural history of the species and to list plausible causes of the decline. The Indian Vulture is a long-lived species with a "slow" life-history (Green et al., 2004). Therefore changes in adult survival have the greatest effect on population trends (Newton, 1979; Sæther and Bakke, 2000; Clark and Martin, 2007). Veterinary NSAIDS such as diclofenac are known to affect this species via increases in mortality (Green et al., 2004; Shultz et al., 2004). Therefore differences in population trends between 
Madhya Pradesh and Rajasthan might result from differing rates of exposure to NSAIDS or other compounding factors.

We do not have data regarding availability of NSAIDS to vultures across Madhya Pradesh and Rajasthan and cannot test for direct correlations. Nor do we have demographic data to determine whether the populations differ in productivity. In 2012, the State of Rajasthan initiated a program that provided free commonly used veterinary and drugs for human use across the state. Veterinary diclofenac was banned at this time, however, the effect of many veterinary drugs for example Nimesulide, on vultures remains insufficiently tested. Cuthbert et al. (2016) showed Nimesulide at elevated tissue concentrations was associated with visceral gout, similar to what diclofenac causes, suggesting that Nimesulide may have similar toxic effects to those of diclofenac. Khatri and Jo (2015) have shown that, Nimesulide, Paracetamol, Chlorzoxazone, Ketoprofen, and Analgin are widely used to treat cattle in Bikaner, Rajasthan. Jorbeer, one of the largest carcass dump sites in India, is located on the outskirts of Bikaner and attracts thousands of vultures. Conversely, Galligan et al. (2020) found that the percentage of pharmacies in Madhya Pradesh selling diclofenac for use in cattle declined from 2014 to 2017. Therefore, it is unclear how veterinary drugs might be contributing to the population trends we report.

Other potential threats to vultures across India include kite festivals, nest disturbance, habitat destruction, and drought (Chhangani, 2004; Kushwaha and Kanaujia, 2010; Hall et al., 2012; Roy and Shastri, 2013). Inclement weather has been shown to affect population trends of cliff nesting vultures (Zuberogoitia et al., 2019). India is also the fourth largest producer of wind energy globally with a number of wind farms in the state of Gujarat (bordering Rajasthan) and at least two in Rajasthan. Wind turbines are a known threat to vultures elsewhere (e.g., Carrete et al., 2012; de Lucas et al., 2012; Sanz-Aguilar et al., 2015; Vasilakis et al., 2016) and are thus of conservation concern in Rajasthan. All these threats could contribute to potential heterogeneity in trends of local populations within India. Disparate trends in neighboring populations can also be caused by movements of individuals (Green, 1995, 1999, 2002). Although we have no hypothesized mechanism, it is possible that the trends in abundance we observed were due to movements of individuals from one state to another. We recommend telemetry studies on Indian Vultures to understand their movements patterns between these two stronghold states that may also help identify hotspots and causes of mortalities.

Our field data collection ended in 2016 and we do not know whether the difference between the populations of Indian Vultures has increased since data collection ceased. The SoIB (2020) shows a strong nationally declining trend, which must be addressed to prevent a second "vulture crisis." Consistent monitoring of occupied nests and their productivity is imperative for proper understanding of population dynamics of Gyps vultures (Benson and McClure, 2020). A long-term adaptive monitoring (Lindenmayer and Likens, 2009) scheme should therefore be devised and implemented for vultures across India. This scheme should not only monitor population levels of vultures, but also hypothesized drivers of population dynamics.
The Indian Vulture almost went extinct at the turn of the 20th century-a robust monitoring program is needed to ensure this critically endangered species endures through the 21 st century.

\section{DATA AVAILABILITY STATEMENT}

The original contributions presented in the study are included in the article/Supplementary Material, further inquiries can be directed to the corresponding author/s.

\section{ETHICS STATEMENT}

Ethical review and approval was not required for the animal study because we did not handle any animals.

\section{AUTHOR CONTRIBUTIONS}

$\mathrm{CM}$ wrote the initial draft. $\mathrm{BR}$ and $\mathrm{CM}$ performed the analysis. MV designed and oversaw data collection. All authors agreed to submission.

\section{FUNDING}

Vulture surveys in India were funded by the Gordon and Betty Moore Foundation, Centre for Development and Finance (Chennai), Iain Allan of Tropical-Ice Safaris, and hundreds of donors who provided support through The Peregrine Fund for the Asian Vulture Crisis.

\section{ACKNOWLEDGMENTS}

We appreciate Leah Dunn for making maps and the M.J. Murdock Charitable Trust for partially funding analysis. We are grateful to the Forest Departments and the Chief Wildlife Wardens of the Indian States of Rajasthan and Madhya Pradesh for permission to conduct work on vultures, Mr. G. V. Reddy and Mr. L. S. Chaudhry, Drs. Asad Rahmani, and Vibhu Prakash of the BNHS, Chris Bowden and Richard Cuthbert of the RSPB, Sharad Vats (Nature Safari Ltd.), Arunav Gogoi, Hema Maira, Balendu Singh, and the staff of Dev Villas, Mr. Shekhawat, Mr. Sudharshan Sharma, Mr. Shafaat Hussein, Mr. Manohar Singh, Mr. Harsh Vardhan, Mr. Tomar, Shamindra Singh (Ken River Lodge), and Shekhar Kolipaka, Mr. Shailendra Tiwari, and the staff of Tiger Den Bandhavgarh, Mr. Jagat Chaturvedi, Pratap Singh Yadav, Teerat, Ragu, Ved Prakash, and Dilsher Khan. Thanks also to Manav Khanduja and his team at Pugdundee Safaris. We also thank ICICI Bank and The Centre for Development Finance, Chennai, India.

\section{SUPPLEMENTARY MATERIAL}

The Supplementary Material for this article can be found online at: https://www.frontiersin.org/articles/10.3389/fevo.2021. 629482/full\#supplementary-material 


\section{REFERENCES}

Benson, P. C., and McClure, C. J. W. (2020). The decline and rise of the Kransberg Cape Vulture colony over 35 years has implications for composite population indices and survey frequency. IBIS (Lond. 1859) 162, 863-872. doi: 10.1111/ibi. 12782

BirdLife International (2021). IUCN Red List for Birds. Available online at: http: //www.birdlife.org on (accessed January 12, 2021).

Buechley, E. R., Santangeli, A., Girardello, M., Neate-Clegg, M. H., Oleyar, D., McClure, C. J. W., et al. (2019). Global raptor research and conservation priorities: tropical raptors fall prey to knowledge gaps. Divers. Distrib 25, 856-869. doi: $10.1111 /$ ddi.12901

Buechley, E. R., and Şekercioğlu, ÇH. (2016). The avian scavenger crisis: Looming extinctions, trophic cascades, and loss of critical ecosystem functions. Biol. Conserv. 198, 220-228. doi: 10.1016/j.biocon.2016.04.001

Carrete, M., Sánchez-Zapata, J. A., Benítez, J. R., Lobón, M., Montoya, F., and Donázar, J. A. (2012). Mortality at wind-farms is positively related to large-scale distribution and aggregation in griffon vultures. Biol. Conserv. 145, 102-108. doi: 10.1016/j.biocon.2011.10.017

Chaudhry, M. J. I., Ogada, D. L., Malik, R. N., Virani, M. Z., and Giovanni, M. D. (2012). First evidence that populations of the critically endangered Longbilled Vulture Gyps indicus in Pakistan have increased following the ban of the toxic veterinary drug diclofenac in south Asia. Bird Conserv. Int. 22, 389-397. doi: 10.1017/S0959270912000445

Chhangani, A. K. (2004). Breeding population of Long-billed vulture (Gyps indicus) in and aroundJodhpur (Rajasthan) India. Vulture News 50, 15-22.

Clark, M. E., and Martin, T. E. (2007). Modeling tradeoffs in avian life history traits and consequences for population growth. Ecol. Modell. 209, 110-120. doi: 10.1016/j.ecolmodel.2007.06.008

Cuthbert, R. J., Dave, R., Chakraborty, S. S., Kumar, S., Prakash, S., Ranade, S. P., et al. (2011a). Assessing the ongoing threat from veterinary non-steroidal antiinflammatory drugs to Critically Endangered Gyps vultures in India. ORYX 45, 420-426. doi: 10.1017/S0030605311000135

Cuthbert, R. J., Taggart, M. A., Saini, M., Sharma, A., Das, A., Kulkarni, M. D., et al. (2016). Continuing mortality of vultures in India associated with illegal veterinary use of diclofenac and a potential threat from nimesulide. ORYX 50, 104-112. doi: 10.1017/S003060531500037X

Cuthbert, R., Parry-Jones, J., Green, R. E., and Pain, D. J. (2007). NSAIDs and scavenging birds: potential impacts beyond Asia's critically endangered vultures. Biol. Lett. 3, 91-94. doi: 10.1098/rsbl.2006.0554

Cuthbert, R., Taggart, M. A., Prakash, V., Saini, M., Swarup, D., Upreti, S., et al. (2011b). Effectiveness of action in India to reduce exposure of gyps vultures to the toxic veterinary drug diclofenac. PLoS One 6:e19069. doi: 10.1371/journal. pone.0019069

de Lucas, M., Miguel Ferrer, Marc, J., Bechard, Antonio, R., and Muñoz. (2012). Griffon vulture mortality at wind farms in southern Spain: distribution of fatalities and active mitigation measures. Biol. Conserv. 147, 184-189. doi: 10. 1016/j.biocon.2011.12.029

Franke, A., McIntyre, C., and Steenhof, K. (2017). "Terminology," in Applied Raptor Ecology: Essentials from Gyrfalcon Research, eds D. L. Anderson, C. J. W. McClure, and A. Franke (Boise, ID: The Peregrine Fund), 33-41.

Galligan, T. H., Mallord, J. W., Prakash, V. M., BhusalL, K. P., Sarowar Alam, A. B. M., Anthony, F. M., et al. (2020). Trends in the availability of the vulture-toxic drug, diclofenac, and other NSAIDs in South Asia, as revealed by covert pharmacy surveys. Bird Conserv. Int. 1-17. doi: 10.1017/s09592709200 00477

Gelman, A., and Rubin, D. (1992). Inference from iterative simulation using multiple sequences. Stat. Sci. 7, 457-472.

Gilbert, M., Watson, R. T., Ahmed, S., Asim, M., and Johnson, J. A. (2002). Breeding and mortality of Oriental White-backed Vulture Gyps bengalensis in Punjab Province. Pakistan. Bird Conserv. Int. 1, 311-326. doi: 10.1017/ s0959270902002198

Gilbert, M., Watson, R. T., Ahmed, S., Asim, M., and Johnson, J. A. (2007). Vulture restaurants and their role in reducing diclofenac exposure in Asian vultures. Bird Conserv. Int. 17, 63-77. doi: 10.1017/S0959270906000621

Green, R. E. (1995). Diagnosing causes of bird population declines. IBIS (Lond. 1859). 137, S47-S55.
Green, R. E. (1999). Diagnosing the causes of bird population declines using comparative methods: the value of data from ringing. Ringing Migr. 19, 47-56. doi: 10.1080/03078698.1999.9674211

Green, R. E. (2002). "Diagnosing causes of population declines and selecting remedial actions," in Conserving Bird Biodiversity: General Principles and Their Application, eds K. Norris and D. J. Pain (Cambridge: Cambridge University Press), 155-172.

Green, R. E., Newton, I., Shultz, S., Cunningham, A. A., Gilbert, M., and Pain, D. J. (2004). Diclofenac poisoning as a cause of vulture population declines across the Indian subcontinent. J. Appl. Ecol. 41, 793-800. doi: 10.1111/j.0021-8901. 2004.00954.x

Hall, J. C., Chhangani, A. K., Waite, T. A., and Hamilton, I. M. (2012). The impacts of la Niña-induced drought on Indian Vulture Gyps indicus populations in Western Rajasthan. Bird Conserv. Int. 22, 247-259. doi: 10.1017/ S0959270911000232

Kellner, K. (2016). Jagsui: A Wrapper Around "rjags" to Streamline "JAGS" Analyses. R Packag. Version 1.4.2. Available online at: https//CRAN.R-project. org/package=jagsUI (accessed April 16, 2019).

Kéry, M., and Schaub, M. (2012). Bayesian Population Analysis Using WinBUGS: A Hierarchical Perspective. London: Elsevier.

Khatri, P. C. (2013). Home range use of winter migratory vultures in and around Jorbeer, Bikaner (Rajasthan) India. Biosci. Discov. 4, 96-99.

Khatri, P. C., and Jo, A. Y. (2015). Vanishing vultures: are veterinary non-steroidal anti-inflammatory drugs (NSAIDs) killing vultures? A study at Jorbeer, Bikaner. Int. J. Pure Appl. Biosci. 3, 217-223.

Kushwaha, S., and Kanaujia, A. (2010). Ecology of vultures in and around Orcha, Madhya Pradesh. Asian J. Exp. Biol. Sci 1, 112-118.

Lindenmayer, D. B., and Likens, G. E. (2009). Adaptive monitoring: a new paradigm for long-term research and monitoring. Trends Ecol. Evol. 24, 482486. doi: 10.1016/j.tree.2009.03.005

Margalida, A., and Ogada, D. (2018). "Old world vultures in a changing environment," in Birds of Prey: Biology and Conservation in the XXI Century, eds J. H. Sarasola, J. M. Grande, and J. J. Negro (Hoboken NJ: Wiley), doi: 10.1002/9781444314076.ch6

McClure, C. J. W., Westrip, J. R. S., Johnson, J. A., Schulwitz, S. E., Virani, M. Z., Davies, R., et al. (2018). State of the world's raptors: distributions, threats, and conservation recommendations. Biol. Conserv. 227, 390-402. doi: 10.1016/j. biocon.2018.08.012

Moulton, C., and Hulsey, E. J. (2002). Kanha Tiger Reserve: Portrait of an Indian National Park. Mumbai. Mumbai: Vakils, Feffer and Simons PVT. LTD.

Naidoo, V., Wolter, K., Cromarty, D., Diekmann, M., Duncan, N., Meharg, A., et al. (2010). Toxicity of non-steroidal anti-inflammatory drugs to Gyps vultures: a new threat from ketoprofen. Biol. Lett. 6, 339-341. doi: 10.1098/rsbl.2009. 0818

Newton, I. (1979). Population Ecology of Raptors. Vermillion. South Dakota: Buteo Books, doi: 10.2307/4081

Oaks, J. L., Gilbert, M., Virani, M. Z., Watson, R. T., Meteyer, C. U., Rideout, B. A., et al. (2004). Diclofenac residues as the cause of vulture population decline in Pakistan. Nature 427, 630-633. doi: 10.1038/nature02317

Ogada, D. L., Keesing, F., and Virani, M. Z. (2012). Dropping dead: Causes and consequences of vulture population declines worldwide. Ann. N. Y. Acad. Sci. 1249, 57-71. doi: 10.1111/j.1749-6632.2011.06293.x

Ogada, D., Shaw, P., Beyers, R. L., Buij, R., Murn, C., Thiollay, J. M., et al. (2016). Another continental vulture crisis: Africa's vultures collapsing toward extinction. Conserv. Lett. 9, 89-97. doi: 10.1111/conl.12182

Pain, D. J., Bowden, C. G. R., Cunningham, A. A., Cuthbert, R., Das, D., Gilbert, M., et al. (2008). The race to prevent the extinction of South Asian vultures. Bird Conserv. Int. 18, S30-S48. doi: 10.1017/s0959270908000324

Plummer, M. (2003). "JAGS: a program for analysis of bayesian graphical models using gibbs sampling," in Proceedings of the 3rd International Workshop on Distributed Statistical Computing (dsc 2003), Vol. 124, (Vienna), 1-10.

Postupalsky, S. (1974). "Raptor reproductive success: some problems with methods, criteria and terminology," in Management of Raptors, eds F. N. Hamerstrom, B. E. Harrell, and R. R. Olendorff (South Dakota: Raptor Research Foundation), 21-31.

Prakash, V. (1999). Status of vultures in Keoladeo National Park, Bharatpur, Rajasthan, with special reference to population crash in Gyps species. J. Bombay Nat. Hist. Soc. 96, 365-378. 
Prakash, V., Bishwakarma, M. C., Chaudhary, A., Cuthbert, R., Dave, R., Kulkarni, M., et al. (2012). The population decline of gyps vultures in india and nepal has slowed since veterinary use of diclofenac was banned. PLoS One 7:e49118. doi: 10.1371/journal.pone.0049118

Prakash, V., Galligan, T. H., Chakraborty, S. S., Dave, R., Kulkarni, M. D., Prakash, N., et al. (2019). Recent changes in populations of critically endangered gyps vultures in India. Bird Conserv. Int. 29, 55-70. doi: 10.1017/s0959270917000545

Prakash, V., Pain, D. J., Cunningham, A. A., Donald, P. F., Prakash, N., Verma, A., et al. (2003). Catastrophic collapse of indian white-backed Gyps bengalensis and long-billed Gyps indicus vulture populations. Biol. Conserv. 109, 381-390. doi: 10.1016/S0006-3207(02)00164-7

R Core Team. (2019). R: A Language and Environment for Statistical Computing. Vienna: R Core Team.

Roy, A., and Shastri, K. (2013). Impact of kite string injuries and temporal variation in types of injuries and illnesses of White-rumped Vultures of central Gujarat. India. J. Threat. Taxa 5, 4887-4892. doi: 10.11609/jott.o3451.4887-92

Sæther, B.-E., and Bakke, $\varnothing$ (2000). Avian life history variation and contribution of demographic traits to the population growth rate. Ecology 81, 642-653. doi: 10.1890/0012-96582000081

Sanz-Aguilar, A., Sánchez-Zapata, J. A., Carrete, M., Benítez, J. R., Ávila, E., Arenas, R., et al. (2015). Action on multiple fronts, illegal poisoning and wind farm planning, is required to reverse the decline of the Egyptian vulture in southern Spain. Biol. Conserv. 187, 10-18. doi: 10.1016/j.biocon.2015.03.029

Shultz, S., Baral, H. S., Charman, S., Cunningham, A. A., Das, D., Ghalsasi, G. R., et al. (2004). Diclofenac poisoning is widespread in declining vulture populations across the Indian subcontinent. Proc. R. Soc. B Biol. Sci. 271, 458-460. doi: 10.1098/rsbl.2004.0223
SoIB (2020). State of India's Birds, 2020: Range, Trends and Conservation Status. The SoIB Partnership, 50.

Swan, G., Naidoo, V., Cuthbert, R., Green, R. E., Pain, D. J., Swarup, D., et al. (2006). Removing the threat of diclofenac to critically endangered Asian vultures. PLoS Biol. 4:0395-0402. doi: 10.1371/journal.pbio.0040066

Swarup, D., Patra, R. C., Prakash, V., Cuthbert, R., Das, D., Avari, P., et al. (2007). Safety of meloxicam to critically endangered Gyps vultures and other scavenging birds in India. Anim. Conserv. 10, 192-198. doi: 10.1111/j.14691795.2006.00086.x

Vasilakis, D. P., Whitfield, D. P., Schindler, S., Poirazidis, K. S., and Kati, V. (2016). Reconciling endangered species conservation with wind farm development: Cinereous vultures (Aegypius monachus) in south-eastern Europe. Biol. Conserv. 196, 10-17. doi: 10.1016/j.biocon.2016.01.014

Zuberogoitia, I., Martínez, J. E., González-Oreja, J. A., Pérez, de Ana, J. M., and Zabala, J. (2019). Factors affecting population regulation of a colonial vulture. IBIS (Lond. 1859). 161, 878-889. doi: 10.1111/ibi.12687

Conflict of Interest: The authors declare that the research was conducted in the absence of any commercial or financial relationships that could be construed as a potential conflict of interest.

Copyright (c) 2021 McClure, Rolek and Virani. This is an open-access article distributed under the terms of the Creative Commons Attribution License (CC BY). The use, distribution or reproduction in other forums is permitted, provided the original author(s) and the copyright owner(s) are credited and that the original publication in this journal is cited, in accordance with accepted academic practice. No use, distribution or reproduction is permitted which does not comply with these terms. 